\section{Strategi Dinas Komunikasi dan Informatika Daerah Istimewa Yogyakarta dalam Melaksanakan Gerakan Literasi Digital}

\section{Theresia Marrie Rosari Chrysaninta Wibowo Putri}

Program Studi Magister Ilmu Komunikasi, Universitas Atma Jaya Yogyakarta, Indonesia

*Korespondensi Penulis. E-mail: chrysanintawibowoputri@gmail.com

\begin{abstract}
Abstrak
Teknologi informasi dan komunikasi saat ini berkembang cukup pesat. Internet sebagai media baru sangat menguasai ruang gerak kehidupan masyarakat. Kebebasan dalam penggunaan internet dapat memberikan dampak negatif misalnya seperti tingkat hoaks yang semakin banyak, cyber bullying, cyber crime, dan hate speech. Perlu adanya suatu kebijakan bagi publik agar dalam penggunaan internet ini dapat memiliki tanggung jawab moral dan sosial. Tulisan ini membahas tentang strategi yang dilakukan oleh Dinas Komunikasi dan Informatika Daerah Istimewa Yogyakarta (Diskominfo DIY) dalam pelaksanaan Gerakan Literasi Digital. Metode yang digunakan adalah deskriptif kualitatif. Diskominfo DIY sebagai bentuk salah satu fungsinya yaitu pengelolaan informasi dan komunikasi publik, maka Diskominfo DIY melakukan berbagai bentuk kerja sama dengan stakeholders untuk melaksanakan gerakan tersebut. Hal ini adalah suatu upaya untuk menumbuhkan budaya bijak dan bertanggung jawab dalam menggunakan internet.
\end{abstract}

Kata kunci: literasi digital, bijak, tanggung jawab moral dan sosial, Diskominfo DIY

\section{Strategy of the Communication and Informatics Office of the Special Region of Yogyakarta in Implementing the Digital Literacy Movement}

\section{Abstract \\ Information and communication} technology is currently developing quite rapidly. Internet as a new media controls the movement space of people's lives. Freedom in the use of the internet can have a negative impact. For example, level of hoax is increasing, cyber bullying, cyber crime, and hate speech. Policy is needed for public, so they can have a moral and social responsibility when use the internet. This paper discusses the strategies from Dinas Komunikasi dan Informatika Daerah Istimewa Yogyakarta (Diskominfo DIY) in the implemation of the digital literacy movement. The method used is descriptive qualitative. As a form of one of its functions, Diskominfo DIY should manage the information and public communication. Because of that functions, DIY cooperate with stakeholders to organize the digital literacy movement. This is an effort to make public wiesely and responsible when using the internet.

Keywords: digital literacy, wise, moral and social responsibility, Diskominfo DIY

\section{A. PENDAHULUAN}

Perkembangan teknologi informasi tidak hanya mampu menciptakan masyarakat dunia global, namun secara materi dapat mengembangkan ruang gerak kehidupan baru bagi masyarakat. 
Tanpa disadari, komunitas manusia telah hidup dalam dua dunia kehidupan, yakni kehidupan masyarakat nyata dan masyarakat maya (cybercommunity). (Setiawan, R., 2013)

Teknologi informasi dan komunikasi (TIK) saat ini berkembang cukup pesat. Internet sebagai media baru sangat menguasai ruang gerak kehidupan masyarakat. Karakteristiknya yang interaktif tentunya berdampak pada aktivitas komunikasi tidak lagi ada batasan jarak ruang dan waktu. Selain itu, akses untuk mencari dan mendistribusikan informasi sangat dipermudah dan cepat dengan adanya internet. Kemudahan ini jika tidak digunakan secara bijak dan bertanggung jawab tentuya akan menjadi permasalahan tersendiri. Misalnya permasalahan yang saat ini seringkali muncul adalah maraknya hoaks, meningkatnya cyber bullying dan hate speech. Oleh sebab itu, pemerintah berkewajiban untuk membuat suatu undang-undang sebagai upaya pencegahan dan meminimalisir dampak negatif dari penggunaan internet. Undang-undang ini diperlukan untuk menjaga pertahanan dan keamanan negara atau secara lebih spesifik dapat dikatakan untuk melindungi masyarakat yang pada dasarnya merupakan pengguna aktif internet, sehingga dapat mencegah terjadinya kejahatan yang mengarah kepada teknologi informasi. Oleh sebab itu, perlu adanya suatu jaminan kepastian hukum dalam menggunakan internet dan melakukan transaksi elektronik.

Di Indonesia, undang-undang tersebut tertuang dalam Undangundang Informasi dan Transaksi Elektronik (UU ITE) Nomor 19 Tahun 2016 yang merupakan perubahan dari UU ITE sebelumnya yaitu Nomor 11 Tahun 2008. Kebijakan ini adalah upaya dari pemerintah Indonesia untuk mengontrol masyarakat agar dapat bijak dan bertanggung jawab dalam menggunakan internet. Berdasar pada kebijakan ini, pemerintah, dalam hal ini adalah Kementerian Komunikasi dan Informatika (Kemenkominfo) perlu mengkomunikasikan kepada masyarakat melalui strategi tertentu untuk mendorong masyarakat semakin sadar dan dapat bersikap bijak dan bertanggung jawab. Kemudahan dalam mengakses internet perlu diimbangi oleh nilai-nilai etika untuk cerdas dalam menggunakannya. Cerdas dalam hal ini seperti yang telah dijelaskan sebelumnya menggunakan internet secara bijak dan bertanggung jawab. Oleh karenanya, penting bagi masyarakat yang mayoritas menggunakan internet untuk dapat menerima, menyaring, menyebarkan informasi serta menggunakan internet secara benar dan tepat guna adalah dengan menumbuhkan budaya literasi digital. Literasi digital secara sederhana dapat didefinisikan sebagai kemampuan untuk memahami dan menggunakan informasi melalui beragam sumber digital (Lankshear dan Knobel dalam Kurnia dan Astuti, 2017). 
Kemenkominfo dalam upayanya menyongsong era 4.0 ini pun, gencar mengembangkan konsep literasi digital dengan harapan dapat mendukung masyarakat Indonesia untuk mampu menguasai pola digital economy, big data dan robotic system. Oleh sebab itu, Kemenkominfo melalui program literasi digital yang dilaksanakan secara berkelanjutan berharap dapat membangun masyarakat Indonesia yang melek digital dan mampu berdaya saing melalui teknologi digital (Kemenkominfo, 2019). Gerakan ini pun tidak hanya dilakukan oleh Kemenkominfo saja. Pemerintah daerah turut serta mendukung gerakan tersebut. Di Yogyakarta, Dinas Komunikasi dan Informatika (Diskominfo) memiliki tanggung jawab untuk pelaksanaannya. Hal ini sesuai dengan arahan dari Gubernur DIY melalui Peraturan Gubernur DIY Nomor 65 Tahun 2018, yang salah satunya menjelaskan tentang fungsi dari Diskominfo DIY yaitu mengenai pelayanan pengelolaan informasi dan komunikasi publik.

Pencarian dengan mesin pencari google scholar dengan rentang waktu dari tahun 2010-2019 menemukan 16.200 artikel ilmiah dengan kata kunci strategi komunikasi publik yang dilakukan oleh pemerintah. Penelitian berkaitan dengan hal tersebut dianggap penting karena antara kebijakan publik dan pelaksanaannya harus berimbang dan dapat memenuhi harapan dari kebijakan tersebut. Oleh sebab itu, strategi pemerintah untuk mengimplementasikannya dalam bentuk program-program yang relevan penting untuk dilaksanakan. Pelaksanaan kebijakan publik adalah implementasi atau penerapan suatu kebijakan publik melalui program, aktivitas, aksi, atau tindakan dalam suatu mekanisme yang terikat pada suatu sistem tertentu. (Ramdhani dan Ramdhani, 2017).

Abdullah Ramdhani dan Muhammad Ali Ramdhani (2017) dalam artikelnya berjudul Konsep Umum Pelaksanaan Kebijakan Publik, mengatakan bahwa pemerintah perlu mengimplementasikan melalui program-program yang terrencana dan terstruktur untuk memenuhi kebijakan yang ada dan bermanfaat bagi publik ataupun masyarakat sekitar. Selain itu, hasil penelitian yang telah dilakukan oleh Chandra Eko Wahyudi Utomo dan Mochamad Hariadi (2016) yang dituangkan dalam artikelnya berjudul Strategi Pembangunan Smart City dan Tantangannya bagi Masyarakat Kota menjelaskan bahwa konsep smart city dapat dibentuk dengan adanya enam karakteristik, yaitu smart governance, smart economy, smart mobility, smart environment, smart people, dan smart living. Hal ini tentunya memerlukan dukungan dari TIK yang memadai. Oleh sebab itu ketersediaan data, informasi yang cepat, keamanan, privasi, infrastruktur, pengembangan aplikasi, dan adaptasi sosial penting untuk dikelola secara terstruktur dan terarah. Melkior N.N. Sitokdana (2015) dalam artikel berjudul Evaluasi Implementasi eGoverment pada Situs Web Pemerintah Kota Surabaya, 
Medan, Banjarmasin, Makassar, dan Jayapura pun menjelaskan bahwa perlu adanya penyempuranaan infrastruktur baik itu berkaitan dengan jaringan, pengelolaan informasi, lingkungan bisnis, dan sumber daya manusia. Jika dirumuskan dan dikelola secara baik dalam bentuk rencana strategis maka implementasi dan pengembangan yang dilakukan dapat menyeluruh dan tepat sasaran.

Tujuan dari penelitian ini adalah untuk mendeskripsikan pengelolaan informasi dan komunikasi yang dilakukan oleh Diskominfo DIY sebagai suatu bentuk strategi komunikasi yanng berkaitan dengan Gerakan Literasi Digital. Berdasar pada temuan dari hasil penelitian yang telah dijelaskan sebelumnya dapat memperkuat membahas topik tersebut. Hal ini bertujuan untuk dapat melihat strategi dari Diskominfo DIY dalam menjalankan program Gerakan Literasi Digital. Selain itu, penting untuk melihat adanya kolaborasi antara berbagai aspek perlu dilakukan oleh Diskominfo DIY untuk dapat melaksanakan program literasi digital yang tepat sasaran.

\section{B. TEORI (Literature Review)}

Untuk menganalisis temuan data yang akan dijelaskan pada bab selanjutnya, penulis menggunakan beberapa landasan dasar. Landasan pertama yang digunakan yaitu strategi komunikasi. Strategi komunikasi menurut Suryadi (dalam Junaidi, 2013) merupakan bagian dari fungsi manajemen dan proses pengambilan keputusan berdasar pada perencanaan matang yang meliputi identifikasi masalah, pengumpulan data, pertimbangan alternatif, dan penentuan tindakan. Strategi komunikasi berdasar pada kesesuaian dari aktivitas yang dilakukan dengan tetap berfokus pada tujuan atau fundamental dari organisasi tersebut. Tujuan dari adanya strategi komunikasi yaitu proses penyampaian pesan yang terarah, jelas, dan efektif sehingga target sasaran dapat memeroleh pemahaman atas pesan yang disampaikan tersebut. Proses pemahaman pesan oleh target sasaran berdasar pada berjalannya program yang dengan baik dilaksanakan oleh suatu organisasi. Oleh sebab itu, seperti telah dijelaskan sebelumnya, persiapan yang matang perlu dilakukan dengan baik oleh suatu organisasi agar tujuan yang ingin diraih tercapai melalui proses penyampaian pesan yang tepat sasaran.

Landasan dasar kedua yang digunakan adalah kebijakan publik. Menurut Wahab (dalam Ramdhani dan Ramdhani, 2017), kebijakan publik adalah suatu tindakan sadar yang mengarah kepada capaian tujuan. Capaian tujuan ini berdasar pada keputusan pemerintah sehingga pada hakekatnya memiliki pola tertentu dan terdiri atas tindakan yang saling berkaitan. Sifat dari kebijakan publik adalah suatu tindakan yang sengaja, sadar dan terukur. Kebijakan publik dapat dinilai secara positif dan negatif. Positif jika menjadi pedoman bagi pemerintah untuk menghadapi suatu 
masalah tertentu. Akan tetapi juga dapat dikatakan negatif jika hanya merupakan suatu keputusan pejabat pemerintah untuk tidak melakukan sesuatu. Evaluasi akan keberhasilan kebijakan publik dapat dikatakan efektif jika dapat memberikan dampak positif bagi publik. Oleh sebab itu kesesuaian antara program dan tujuan yang ingin dicapai oleh pemerintah dan proses penerimaan program di publik sangat memengaruhi keberhasilan kebijakan publik tersebut. Atau dengan kata lain, dalam pelaksanaan kebijakan dapat efektif melalui rancangan program yang memadai dan terstruktur dalam proses pelaksanaannya (Pülzl dan Treib dalam Ramdhani dan Ramdhani, 2017). Efektif dalam hal ini mencakup dari kesesuaian dari proses produksi kebijakan publik, proses distribusi (penyampaian informasi) akan kebijakan publik tersebut yang tertuang dalam pelaksanaan, dan dampak dari kebijakan publik itu sendiri.

Berkaitan dengan program yang dijalankan oleh suatu organisasi, maka penelitian ini tidak dapat terlepas dari konsep komunikasi publik organisasi. Oleh sebab itu, landasan ketiga dalam penelitian ini adalah mengenai komunikasi publik. Andre Hardjana (2019) dalam bukunya berjudul Komunikasi Organisasi: Strategi Interaksi dan Kepemimpinan, merangkum berbagai definisi mengenai komunikasi publik. Akan tetapi, definisi yang relevan dengan penelitian ini adalah komunikasi impersonal yaitu melibatkan individu perwakilan dari suatu organisasi dan penerima dari pesan tersebut adalah khalayak banyak. Pesan dalam hal ini memiliki relevansi untuk khalayak tersebut. Proses dari komunikasi publik itu terencana, terprediksi, dan formal. Tujuannya adalah untuk menyampaikan pesan dan mempersuasi khalayak. Oleh sebab itu, diharapkan khalayak penerima pesan dapat mencapai kesamaan makna dari pesan yang disampaikan. Komunikasi publik pada dasarnya adalah komunikasi strategis untuk menjawab tantangan dari perubahan drastis lingkungan dan untuk mempertahankan visi misi suatu organisasi. Sehingga, dapat dikatakan bahwa komunikasi memegang kendali dalam upayanya untuk memberikan dampak pada khalayak. Efektivitas suatu komunikasi publik itu hakikatnya berdasar pada retorika yang terdiri dari tiga jenis faktor bagi pembicaranya, yaitu ethos (terpercaya), pathos (perasaan hati khalayak), dan logos (penalaran isi pesan). Pelaku dari komunikasi publik sebagai pembicara perlu memiliki kredibilitas, keteladanan, kejujuran, kekuasaan, kompetensi, dan daya tarik bagi khalayak. Efektivitas ini akan berdampak pada pengelolaan suatu isu dan membentuk adanya opini publik. Ogansisasi perlu memiliki kepekaan terhadap informasi yang muncul di lingkungan. Hal ini menjadi peringatan dini bagi organisasi untuk dapat mengambil tindakan atas informasi tersebut.

Landasan keempat yang digunakan oleh penulis adalah etika 


\section{Vol.1 No.2 Desember 2019}

media. Media adalah sarana utama bagi publik dalam aktivitas komunikasi. Media dalam konteks etika komunikasi idealnya adalah dapat menyeimbangkan aspek kebebasan berekspresi dan aspek tanggung jawab. Nick Couldry (dalam Ward, 2013) menjelaskan bahwa pada dasarnya konsep dari internet adalah untuk memenuhi nilai kebebasan sebagai kebebasan untuk pertukaran informasi. Kebebasan dalam hal ini adalah untuk menciptakan adanya otonomi demokrasi. Jaminan terciptanya otonomi demokrasi itu dapat tumbuh ketika hak untuk berkomunikasi di ruang publik itu dihormati dan diterapkan dengan baik. Akan tetapi, hambatan yang sering terjadi adalah ketika muncul kepentingan kelompok yang sengaja mengeksploitasi suatu informasi yang seringkali berbahaya dan anti sosial.

Nick Couldry dalam tulisannya berjudul Why Media Ethics Still Matters pun menekankan bahwa etika media sangat penting sebagai upaya untuk pencarian kebenaran. Tulisan ini merupakan salah satu dari kumpulan tulisan yang diterbitkan dalam buku yang berjudul Global Media Ethics: Problems and Perspectives (Ward, 2013). Di dalam tulisan tersebut dijelaskan bahwa tanpa adanya praktik yang ditujukan pada kebenaran, aktivitas dan pemenuhan kebutuhan informasi bagi publik tidak mungkin dilakukan. Maka etika media sebagai suatu upaya menjamin terbentuknya suatu kebenaran perlu diberlakukan untuk menjamin hak berkomunikasi terutama di ranah publik. Oleh sebab itu, dialog dan tanya jawab bersama, untuk membentuk kesepakatan fakta sehinga secara bertahap membangun norma nantinya akan menjadi suatu konsensus. Haryatmoko (2007) pun menjelaskan bahwa dengan adanya etika diharapkan dapat memecahkan permasalahan antara kebebasan berekspresi dan tanggung jawab media sebagai sarana utama untuk pertukaran informasi bagi publik.

Selain itu, Raphael Cohen dan Almagor dalam tulisannya berjudul Responsibility of Net Users yang juga merupakan salah satu kumpulan tulisan dari buku yang berjudul The Handbook of Global Communication and Media Ethics Volume I (Fortner dan Fackler, 2011), menjelaskan tentang potensi risiko penggunaan internet. Risiko ini muncul ketika internet digunakan untuk melemahkan kesejahteraan publik sebagai makhluk otonom yang hidup dalam masyarakat bebas. Oleh sebab itu, kemampuan publik sebagai pengguna internet untuk mewujudkan masyarakat demokratis penting untuk ditumbuhkan. Kemampuan publik dalam hal ini meliputi tanggung jawab akan moral dan sosial dari pengguna internet. Sehingga publik, sebagai pengguna internet, dapat menentukan langkah-langkah untuk mengetahui perbedaan baik dan buruk pada saat menerima informasi di internet sehingga dapat menentukan sikap atas penerimaan informasi tersebut. 


\section{METODE}

Penelitian ini menggunakan pendekatan deskriptif kualitatif. Kriyantono (2010) menjelaskan bahwa pendekatan kuallitatif bertujuan untuk menjelaskan fenomena dengan cara mengungkapkan masalah sesuai dengan fakta dan keadaan yang sebenarnya di lapangan. Neuman (2014) pun menjelaskan bahwa penelitian kualitatif adalah deskripsi tersirat yang dituangkan dalam bentuk narasi atas sebuah tindakan spesifik yang menghubungkan ide dengan data. Hal ini tentunya sesuai dengan tujuan dari penelitian ini untuk mendeskripsikan serta menganalisis strategi komunikasi yang dilakukan oleh Diskominfo DIY berkaitan dengan Gerakan Literasi Digital melalui beberapa landasan yang digunakan oleh penulis.

Teknik pengumpulan data adalah dengan menggunakan kajian pustaka menggunakan sumber tulisan yang relevan dengan topik dalam penelitian ini. Selain itu, penulis juga menggunakan wawancara terhadap narasumber yaitu Kepala Diskominfo DIY mengenai strategi yang dilakukan oleh Diskominfo DIY melihat situasi dan kondisi yang ada di DIY saat ini.

Penulis kemudian menganalisis penelitian ini dengan mendeskripsikan perbandingan antara landasan teori yang digunakan oleh penulis dengan hasil temuan penulis pada saat pengumpulan data sehingga dapat dibentuk adanya suatu kesesuaian atau ketidaksesuaian dalam kesimpulan dari penelitian ini.

\section{HASIL DAN PEMBAHASAN}

Berkaitan dengan kelembagaan Pemerintah Daerah DIY, Diskominfo DIY sesuai dengan Perda Keistimewaan Nomor 1 Tahun 2018 merupakan perangkat daerah yang terfokus pada bidang komunikasi dan informatika. Diskominfo DIY sebagai suatu perangkat daerah dalam bidang komunikasi dan informatika memiliki kewajiban untuk memenuhi tuntutan masyarakat kaitannya dalam pelayanan bidang kominfo. Hal ini diharapkan dapat mewujudkan penyelenggaraan pemerintahan yang transparan dan akuntabel yang menyesuaikan dengan era keterbukaan informasi. Aktivitasaktivitas yang dilakukan oleh Diskominfo DIY tertuang dalam Perencanaan Strategis yang dinamakan Renstra Diskominfo DIY. Hal ini sesuai dengan aturan mengenai Perangkat Daerah yaitu di dalam UU Nomor 25 Tahun 2004 perihal Sistem Perencanaan Pembangunan Nasional Pasal 19 bahwa Perangkat Daerah perlu memiliki suatu ketetapan perangkat perencanaan berdasar pada peraturan yang dinamakan Rencana Strategis Perangkat Daerah (Renstra PD). Renstra Diskominfo DIY sebagai suatu dokumen menguraikan tentang rancangan perencanaan strategis yang dilaksanakan dalam kurun waktu lima tahun (2017-2022) Tujuan dari Renstra Diskominfo DIY yaitu menjamin adanya konsistensi antara perencanaan dan pemilihan program 
serta kegiatan yang sesuai dengan kebutuhan dan kondisi daerah serta sebagai pedoman perencanaan dan alat kontrol terhadap pelaksanaan yang akan dilakukan. (Dinas Komunikasi dan Informatika Daerah Istimewa Yogyakarta, 2019).

Menurut Rony Primanto Hari, selaku Kepala Diskominfo DIY, kemajuan TIK memberikan manfaat secara positif tetapi juga dapat memberikan dampak buruk bagi masyarakat. Positif itu jika masyarakat mampu menggunakan internet sehingga dapat memberikan manfaat dan nilai plus bagi dirinya akan tetapi juga dapat menjadi negatif ketika masyarakat tidak dapat mengontrol sehingga internet memengaruhi secara krusial bagi keseharian mereka. Mayoritas masyarakat menghabiskan waktunya dengan menggunakan internet, hal ini mengakibatkan masyarakat dengan mudah menerima banyak informasi dari berbagai media. Ketika masyarakat tidak mampu memilah dan menganalisis secara bijak, maka masalah seperti hoaks yang di Indonesia semakin marak terjadi. Selain itu ketika internet digunakan untuk kepentingan seseorang tanpa batas maka cyber crime akan semakin sering terjadi. Oleh sebab itu, karena adanya kebebasan dan kemudahan dalam menggunakan internet, disusun dan ditetapkan suatu dalam UU ITE. UU ini menjadi dasar bagi masyarakat di Indonesia untuk dapat bijak dalam menggunakan internet. Berikut adalah enam pasal yang dijelaskan oleh beliau terkait hal tersebut adalah a) Pasal 45
Ayat 1 berkaitan dengan pelanggaran kesusilaan; b) Pasal 45 Ayat 2 berkaitan dengan perjudian; c) Pasal 45 Ayat 3 berkaitan dengan penghinaan dan pencemaran nama baik; d) Pasal 45 Ayat 4 berkaitan dengan pemerasan ataupun pengancaman; e) Pasal 45A Ayat 1 berkaitan dengan penyebaran hoaks (berita bohong) yang berakibat pada kerugian public; f) Pasal 45A Ayat 2 berkaitan dengan penyebaran kebencian ataupun permusuhan individu atau kelompok berdasar pada suku, ras, agama, dan antar golongan (SARA)

Oleh sebab itu, penekanan untuk bijak dalam penggunaan internet khususnya bermedia sosial ini penting untuk dilakukan. Bijak artinya adalah menghormati hak orang lain untuk berpendapat meskipun pendapat itu berbeda dari pendapat diri sendiri. Termasuk dalam aspek menghormati adalah untuk dapat menjaga perasaan ataupun emosi dalam mengutarakan pendapat. Selain itu, adalah perlu menjaga keamanan data pribadi. Jejak digital itu tidak dapat dihapuskan maka dari itu, pemerintah menghimbau untuk tidak mengobral data pribadi. Tata bahasa dalam bermedia sosial pun penting untuk dikelola masing-masing individu. Di dalam hal ini adalah tidak tendensius ataupun melecehkan sehingga dapat mencegah kemungkinan munculnya SARA.

Distribusi informasi yang semakin terbuka dan bebas mengakibatkan kecenderungan publik untuk mengonsumsi konten dunia 
maya secara instan sehingga memungkinkan munculnya berita bohong (hoaks) (Humas DIY, 2018). Hal ini dapat terjadi dikarenakan kemajuan teknologi yang tidak diimbangi oleh budaya kritis masyarakat Indonesia. Budaya kritis ini pun didukung oleh faktor berikut yaitu sebagai ajang aktualisasi diri karena dapat menyebarkan berita secara cepat tanpa mengetahui dan mencari tahu kebenarannya. Selain itu, hoaks terjadi karena adanya kesengajaan yang dibentuk untuk kepentingan individu ataupun kelompok tertentu. Oleh sebab itu, hoaks menjadi sangat berbahaya karena dapat menumbuhkan perselisihan bahkan kebencian yang dapat merusak persatuan dan kesatuan bangsa Indonesia. Hoaks pun dapat berakibat pada rusaknya reputasi seseorang. Maka dari itu,perlu adanya suatu kebijakan seperti yang tertuang dalam UU ITE agar masyarakat dapat bijak bersikap meski adanya aspek kebebasan dalam penggunaannya.

Berkaitan dengan berbagai permasalahan yang dimungkinkan muncul karena penggunaan internet dan berlandaskan UU ITE, Diskominfo DIY memiliki rangkaian kegiatan untuk mengupayakan agar masyarakat di Yogyakarta dapat bijak dalam menggunakannya. Hal ini pun tidak terlepas dari Gerakan Literasi Digital. Gerakan ini penting dilakukan untuk dapat menumbuhkan budaya positif dari masyarakat. Terutama bagi Diskominfo DIY yang memiliki visi untuk mewujudkan Jogja Cyber
Province dan masyarakat informasi menuju peradaban baru yang mendukung keistimewaan DIY (Dinas Komunikasi dan Informatika Daerah Istimewa Yogyakarta, n.d). Diskominfo DIY secara aktif terlibat dan bersinergi dengan berbagai mitra ataupun stakeholders yang memiliki visi dan misi yang sama. Keterlibatan dalam hal ini yaitu Diskominfo sebagai pemerintah daerah bekerja sama dengan akademisi, media, komunitas, dan dunia usaha. Langkah-langkah yang dilakukan oleh Diskominfo untuk melaksanakan Gerakan Literasi Digital di Yogyakarta adalah a) melakukan koordinasi intensif baik itu dengan Kemenkominfo, BSSN, Polda DIY, ataupun instansi terkait lainnya; b) menyediakan fasilitas bagi komunitas digital. Misalnya yang telah dilakukan oleh Diskominfo yaitu mendirikan coworking space; c) mengintensifkan kegiatan cyber patrol bekerja sama dengan komunitas programmer; d) membentuk Bregada Cyber; e) membentuk forum Admin Plat Merah; f) mengadakan pertemuan dengan admin dari berbagai media sosial yang ada di Yogyakarta; g) mengadakan forum komunikasi rutin dengan Masdjo

Diskominfo DIY sebagai suatu bentuk upaya mengembangkan industri kreatif digital mendirikan Diskominfo Co-working Space yang diresmikan oleh Kepala Diskominfo DIY pada tanggal 24 Agustus 2018 sebagai suatu area khusus bagi individu ataupun komunitas tertentu untuk dapat menyalurkan ide dan gagasan (Dinas Komunikasi dan 
Informatika Daerah Istimewa Yogyakarta, n.d). Pembentukan Bregada Cyber merupakan kesepakatan dari hasil diskusi yang dijembatani oleh Diskominfo DIY dengan 25 perwakilan dari admin media sosial untuk meminimalisir ataupun bahkan mencegah konten negatif (Azmi, 2019). Pembentukan dan pengelolaan forum Admin Plat Merah ini merupakan suatu forum dari admin media sosial pemerintah daerah se-DIY yang rutin dilakukan sebagai suatu ruang bagi para admin untuk dapat saling bertukar informasi, koordinasi, dan menambah pengetahuan bersama (Dinas Kominfo, 2019). Selain itu berbagai bentuk kerja sama yang dikelola oleh Diskominfo DIY mengarah kepada penyelenggaran dan pengelolaan untuk pembuatan konten positif, seperti bimbingan teknologi penggunaan internet sehat, diseminasi konten positif, pemasangan wifi dan pendampingan digital marketing di 50 titik UMKM dan penyelenggaraan workshop baik itu dengan komunitas kreatif, mahasiswa, ataupun penyandang disabilitas.

Berdasar pada temuan data yang telah dijelaskan pada bab sebelumnya, dapat dilihat bahwa adanya kesesuaian antara landasan analisis yang digunakan dalam penelitian ini dengan penerapan yang telah dilakukan oleh Diskominfo DIY. Landasan pertama yang digunakan untuk menganalisis penelitian ini adalah strategi komunikasi sebagai suatu fungsi manajemen yang berdasar pada perencanaan matang yang meliputi identifikasi masalah, pengumpulan data, atlernatif pertimbangan dan penentuan tindakan sehingga dampak berdampak proses penyampaian pesan yang terarah, jelas, dan efektif.

Renstra Diskominfo DIY menjadi suatu terapan strategis dari Diskominfo DIY untuk dapat menjamin adanya konsistensi antara perencanaan dan pemilihan program serta kegiatan yang sesuai dengan kebutuhan dan kondisi daerah. Selain itu, Renstra dapat menjadi suatu pedoman perencanaan dan alat kontrol terhadap pelaksanaan yang akan dilakukan. Kebutuhan dan kondisi pada suatu daerah menjadi titik utama dari Diskominfo DIY untuk merancang suatu program dan tentunya diaplikasikan melalui aktivitas-aktivitas yang diharapkan dapat memberikan kontribusi positif kepada masyarakat DIY. Program Gerakan Literasi Digital yang disebutkan oleh Rony Primanto Hari merupakan suatu penerapan yang dilakukan oleh Diskominfo DIY melihat bahwa penggunaan internet dapat memberikan dampak signifikan bagi masyarakat baik itu dampak positif ataupun dampak negatif.

Penerapan dari Renstra Diskominfo DIY ini menjadi lebih terkoordinasi dengan adanya sinergi dengan pihak-pihak terkait agar program yang telah direncanakan dapat terlaksana dan lebih dapat tepat sasaran sesuai dengan tujuan yang ingin diraihnya. Misalnya seperti yang telah diuraikan sebelumnya, Diskominfo DIY bersinergi dengan instansi pemerintah lainnya, seperti 
Polda DIY, berkaitan dengan sanksi bagi pelanggar UU ITE. Konsistensi dari tujuan yang ingin diraih oleh Diskominfo DIY yaitu penekanan untuk bijak dalam penggunaan internet khususnya bermedia sosial pun terlihat sesuai dengan programprogram yang telah disusun dan diterapkan, misalnya seperti menyediakan co-working space sebagai sarana bagi komunitas digital untuk dapat menumbuhkan dan mengembangkan manfaat internet positif dan berguna bagi masyarakat di Yogyakarta.

Landasan kedua dalam penelitian ini yaitu mengenai kebijakan publik yang merupakan suatu keputusan pemerintah sehingga pada hakekatnya memiliki pola tertentu dan terdiri atas tindakan yang saling berkaitan. Berdasar pada hasil yang ditemukan dalam penelitian ini, kebijakan publik ini tertuang melalui UU ITE yang menjadi dasar bagi Diskominfo DIY untuk melaksanakan program Gerakan Literasi Digital. Seperti yang telah dijelaskan sebelumnya, UU ITE dibentuk karena adanya berbagai permasalahan yang muncul akibat dari penggunaan internet dan media sosial yang tidak bijak di masyarakat sehingga menumbuhkan efek negatif. Oleh sebab itu, pemerintah berkaitan dengan kebijakan yang tertuang dari UU ITE tersebut membentuk Gerakan Literasi Digital dengan tujuan untuk menumbuhkan budaya bijak dan bertanggung jawab ketika menggunakan internet dan media sosial. Tentunya kebijakan ini adalah suatu tindakan yang memang dilakukan dengan sengaja, sadar, dan terukur. Kebijakan publik yang dilakukan oleh pemerintah yang kemudian dilaksanakan dengan Gerakan Literasi Digital sebagai suatu upayanya ini memiliki nilai positif. UU ITE dan Gerakan Literasi Digital menjadi pedoman bagi pemerintah untuk menghadapi permasalahan yaitu maraknya konten negatif dan akibat yang dapat muncul dari konten tersebut. Gerakan Literasi Digital ini pun dilaksanakan terstruktur dengan rancangan berbagai aktivitas yang dilakukan oleh pemerintah untuk mencapai tujuan yang diinginkan. Aktivitas ini dijelaskan pada bagian sebelumnya yaitu melalui berbagai kerja sama yang dilakukan oleh Diskominfo DIY dengan stakeholders yang memiliki visi dan misi yang sama. Akan tetapi, keefektifan dari Gerakan Literasi Digital ini belum dapat dibahas dari penelitian ini. Oleh sebab itu, dalam penelitian selanjutnya dapat dilakukan penelitian terkait dengan keefektifan dari program dari Gerakan Literasi Digital.

Berkaca pada landasan ketiga, yaitu konsep dari komunikasi organisasi publik. Diskominfo DIY merupakan perwakilan dari suatu organisasi yang melibatkan masyarakat di Yogyakarta sebagai publiknya untuk menyampaikan pesan melalui Gerakan Literasi Digital sebagai suatu upaya untuk menumbuhkan budaya literasi digital. Pesan ini seperti yang telah dijelaskan sebelumnya adalah suatu respon yang muncul karena adanya permasalahan yang dari kebebasan dalam 
penggunaan internet. Sehingga dapat dikatakan bahwa pesan yang terbentuk memiliki relevansi untuk khalayak di Yogyakarta. Proses penyampaian pesan ini bertujuan untuk mempersuasi khalayak untuk menumbuhkan budaya literasi digital melalui aktivitas yang terrencana, terstruktur, terprediksi, dan formal. Hal ini dapat dilihat dari berbagai aktivitas yang dilakukan oleh Diskominfo DIY dengan stakeholders untuk memproduksi konten-konten positif dan meminimalisir atau bahkan mencegah konten negatif yang muncul di internet. Diskominfo DIY dalam melaksanakan aktivitas tersebut telah menjalankan salah satu fungsinya yang tertuang dalam Peraturan Gubernur DIY Nomor 65 Tahun 2018, yaitu mengenai pelayanan pengelolaan informasi dan komunikasi publik. Penerapan fungsi ini dapat dilihat dari aktivitas yang dilakukan oleh Diskominfo DIY yang memilki tujuan memberikan informasi, mengedukasi, dan mempersuasi publik (dalam hal ini adalah masyarakat di Yogyakarta) untuk dapat bijak dan bertanggung jawab dalam menggunakan internet.

Berkaitan dengan landasan kempat yaitu etika media dan etika pengguna internet. Dapat dilihat dalam hal ini, Diskominfo DIY, sebagai suatu Perangkat Daerah yang memiliki kewajiban mengelola pelayanan di dalam bidang kominfo maka perlu menyampaikan dan mengelola informasi dan komunikasi berkaitan dengan pelaksanaan program Gerakan Literasi Digital. Sebagai komunikan utama, Diskominfo DIY, memiliki strategi dalam program ini dengan menjalin kerja sama dan bersinergi dengan berbagai stakeholders yang memiliki visi misi yang sama dan juga dapat memengaruhi masyarakat Yogyakarta untuk dapat menumbuhkan budaya literasi digital. Keterbukaan dalam prosesnya serta membuat suatu ruang publik untuk dapat saling berkomunikasi, berdiskusi, sehingga menumbuhkan ide baru atau kesepakatan bersama telah dilakukan oleh Diskominfo DIY. Melalui co-working space yang bebas biaya pun, Diskominfo DIY telah memfasilitasi dan mendukung masyarakat di Yogyakarta untuk cerdas dalam menggunakan perangkat digital. Sedangkan melalui workshop ataupun sesi diskusi, telah berupaya untuk memberikan informasi, edukasi terkait pentingnya literasi digital dan ancaman ketika masyarakat, khususnya dalam hal ini di Yogyakarta, tidak cerdas dan bijaksana dalam menggunakan internet dan media sosial. Upaya-upaya tersebut adalah suatu penerapan strategi yang dilakukan oleh Diskominfo DIY untuk mensosialisasikan program Gerakan Literasi Digital sehingga dapat membentuk masyarakat Yogyakarta yang literat. Harapan dari Diskominfo ini sendiri pun akan mengarah kepada masyarakat Yogyakarta untuk sadar dan bersikap bijak dan bertanggung jawab sebagai representasi dari tanggung jawab moral dan sosialnya sebagai pengguna internet. 


\section{E. SIMPULAN DAN SARAN}

1. Kesimpulan

Diskominfo DIY dalam fungsinya untuk mengelola informasi dan komunikasi kepada publik, telah dijalankan sesuai dengan kondisi dan situasi yang diperlukan oleh masyarakat DIY terkait dengan strategi dalam program Gerakan Literasi Digital. Diskominfo DIY sebagai media utama pemberi informasi kepada publik, dalam hal ini adalah masyarakat Yogyakarta, telah memberikan ruang yang cukup terbuka karena tidak hanya menjalankan komunikasi satu arah melainkan melibatkan proses diskusi untuk mencapai suatu kesamaan pemahaman dari pesan yang disampaikan. Pesan dalam hal ini adalah pentingnya literasi digital itu ditumbuhkan dan dilaksanakan. Mengacu pada kebijakan dari UU ITE yang muncul karena adanya penyalahgunaan dalam kebebasan menggunakan internet, maka Diskominfo DIY menjalin kerja sama dengan berbagai pihak untuk memberikan informasi dan memfasilitasi masyarakat Yogyakarta untuk dapat bijak dan bertanggung jawab dalam menggunakan internet. Etika sangat penting untuk ditumbuhkan dalam hal ini sehingga masyarakat Yogyakarta, sebagai pengguna internet memiliki tanggung jawab moral dan sosial saat menggunakannya.

\section{Saran}

Penelitian ini terfokus untuk meneliti dan menganalisis Diskominfo
DIY sebagai komunikator atau pihak yang memproduksi dan mendistribusikan pesan. Oleh sebab itu, perlu dilakukan analisis lanjutan yang dilakukan terhadap Diskominfo DIY, yaitu berkaitan dengan efektivitas dari program Gerakan Literasi Digital yang telah dilakukan oleh Diskominfo DIY. Hal ini dapat menjadi relevan karena dapat melihat manfaat yang telah diterima dari program yang telah direncanakan dan dilaksanakan oleh Diskominfo DIY sehingga dapat memberikan gagasan berkaitan keberlanjutan program Gerakan Literasi Digital.

\section{DAFTAR PUSTAKA}

Azmi, S, A (2019). Bregada Cyber Akan Jaga Jogja Dari Konten Negatif. Retrieved from https://news.harianjogja.com/r ead/2019/04/13/500/985005 bbregada-cyber-akan-jagajogja-dari-konten-negatif-

Dinas Komunikasi dan Informatika Daerah Istimewa Yogyakarta. (2019, July). Optimalisasi Media Sosial bagi Admin Plat Merah DIY. Retrieved from https://jogjaprov.go.id/berita/ detail/7874-optimalisasimedia-sosial-bagi-admin-platmerah-diy

Dinas Komunikasi dan Informatika Daerah Istimewa Yogyakarta. (n.d). Diskominfo Co Working Space. Retrieved from http://diskominfo.jogjaprov.go. id/diskominfo-co-workingspace/ 
Dinas Komunikasi dan Informatika Daerah Istimewa Yogyakarta. (2019, Mei). Dokumen Renstra 2017-2022 (Perubahan Kedua). Retrieved from https://diskominfo.jogjaprov.go .id/file/detail/dokumenrenstra-2017-2022-perubahankedua

Dinas Komunikasi dan Informatika Daerah Istimewa Yogyakarta. (n.d). Visi Misi. Retrieved from https://diskominfo.jogjaprov.go .id/visi-misi

Fortner, R, S dan Fackler, P, M. (2011). The Handbook of Global Communication and Media Ethics Volume 1. Blackwell Publishing Ltd. A John Wiley \& Sons, Ltd., Publication. Chichester, West Sussex.

Hardjana, Andre (2019). Komunikasi Organisasi: Strategi Interaksi dan Kepemimpinan. Depok: Rajawali Pers Divisi Buku Perguruan Tinggi PT Raja Grafindo Persada.

Haryatmoko. (2007). Etika Komunikasi: Manipulasi Media, Kekerasan, dan Pornografi. Penerbit PT Kanisius: Yogyakarta.

Humas DIY. (2018, November). Kemenkominfo Gencarkan Literasi Digital Menyongsong Era 4.0. Retrieved from https://jogjaprov.go.id/berita/ detail/kemenkominfogencarkan-literasi-digitalmenyongsong-era-4-0.

Humas DIY. (2018, November). Perangi Hoax melalui Digital Smart Media. $\quad$ Retrieved from https://diskominfo.jogjaprov.go .id/berita/baca/perangi-hoaxmelalui-digital-smart-media, Junaidi, Muhammad. (2013). Strategi Komunikasi Dinas Kebersihan dan Pertamanan Kota Samarinda dalam Pelaksanaan Program Samarinda Hijau Bersih dan Sehat (HBS) pada RT 07 Kelurahan Mugirejo. eJournal Ilmu Komunikasi 1(3), 408423.

Kriyantono, Rachmat. (2010). Teknik Praktis Riset Komunikasi: Disertai Contoh Praktis Riset Media, Public Relations, Advertising, Komunikasi Organisasi, Komunikasi Pemasaran. Jakarta: Kencana.

Kurnia, N, dan Astuti, S, I. (2017). Peta Gerakan Literasi Digital di Indonesia: Studi tentang Perilaku, Ragam Kegiatan, Kelompok Sasaran dan Mitra. Jurnal INFORMASI Kajian Ilmu Komunikasi Volume 47 Nomor 2, 149-166.

Neuman,W, L (2014). Social Research Methods: Qualitative and Quantitative Approaches. Essex: Pearson Education Limited.

Ramdhani, A, Muhammad Ali Ramdhani. (2017). Konsep Umum Pelaksanaan Kebijakan Publik. Jurnal Publik Volume 11 Nomor 1, 1-12.

Setiawan, Rudy. (2013). Kekuatan New Media dalam Membentuk Budaya Populer di Indonesia (Studi Tentang Menjadi Artis Dadakan Dalam Mengunggah 
Video Musik Di Youtube. EJournal Ilmu Komunikasi Volume I Nomor 2, 355-374.

Sitokdana, M, N, N. (2015). Evaluasi Implementasi eGoverment pada Situs Web Pemerintah Kota Surabaya, Medan, Banjarmasin, Makassar, dan Jayapura. Jurnal Buana Informatika Volume 6 Nomor 4, 289-300.

Utomo, C, E, W, dan Hariadi, M. (2016). Strategi Pembangunan Smart City dan Tantangannya bagi Masyarakat Kota. Jurnal Strategi dan Bisnis Volume 4 Nomor 2, 159-176.

Ward, S.J.A. (2013). Global Media Ethics Problems and Perspectives. (ec). Blackwell Publishing Ltd. A John Wiley \& Sons, Ltd., Publication. Chichester, West Sussex. 